\title{
Competition Law and Europe's open Borders: The Case of Motor Vehicle Distribution in Switzerland
}

\author{
Simon J. Evenett ${ }^{1}$ and Michael Meier ${ }^{2}$ \\ SIAW, University of St. Gallen and CEPR / SIAW, University of St. Gallen
}

This paper contains an independent ${ }^{3}$ empirical analysis of the effect of a Notice, issued by the Swiss Competition Commission in 2002 concerning vertical agreements between manufacturers and distributors of motor vehicles, on the degree to which the subsequent prices of cars in Switzerland exceeded those charged on the same models in neighbouring countries. Evidence presented here implies a non-transitory reduction in the degree of price discrimination against Swiss customers of medium- and large-sized cars in the years after the Notice came into effect. The total gain to Swiss buyers of cars is very conservatively estimated to be six times the total cumulative budget of the Swiss Competition Commission during the years 2003-2006; the best estimate of those gains exceed a quarter of a billion Swiss Francs during the same period. By 2006 the cumulative price reduction of the Swiss Competition Commission's action resulted in average savings per medium- and large-sized car that are estimated to be 929 and 2113 Swiss Francs, respectively. Moreover, the recurring annual gain to Swiss consumers of this single action by the Swiss Competition Commission is conservatively estimated to exceed ten times the latter's current annual budget, providing some indication of the "value for money" that effective competition law can have, even in economies with ostensibly open borders.

\section{Introduction}

Ever since the Principle of Comparative Advantage was enunciated over 200 years ago, economists and others have argued that one of the benefits

1 Professor of International Trade and Economic Development and Director of the Swiss Institute of International Economics and Applied Economic Research, University of St. Gallen. Professor EvENETT is also Co-Director of the Europe-wide Programme of International Trade and Regional Economics, Centre for Economic Policy Research (CEPR) and has served as rapportuer at a number of leading international conferences on competition law and policy, including those organised by the International Competition Network and the Organisation for Economic Co-operation and Development. He can be contacted at the following email address: simon.evenett@unisg.ch.

2 When the research for this paper was conducted Michael MEIER was a staff member at the Swiss Institute of International Economics and Applied Economic Research. He is now a member of the Swiss Diplomatic Service, posted abroad. Naturally, the opinions expressed in this paper are his own and do not reflect that of any official body. His email address is: michael.meier.ch@gmail.com

3 In short independent here means "independent of the Swiss Competition Commission." That is, the authors collected all of the data for this study themselves (a process that took a substantial amount of time and effort), conducted the empirical analysis themselves, and drafted this text themselves without any guidance or funding from the Swiss Competition Commission. The Swiss Competition Commission did not make any information available to the authors that is not available to the general public. In order to better understand the decision taken by the Swiss Competition Commission, the authors did speak to officials at that body. In response to a request from the Swiss Competition Commission, the authors did provide a summary of the findings of this study earlier in the year. 
of a nation integrating its economy into world markets is to take advantage of the opportunities associated with production specialisation. Such specialisation inevitably involves a country's firms producing only a subset of the range of the products that its consumers wish to buy requiring, then, some of those products to be imported. It has also been argued that foreign firms will compete for the attention of a country's consumers and that when sufficiently intense this competition will result in prices being driven down to marginal (incremental) costs, so attaining one of the efficiency yardsticks used by economists to evaluate market outcomes. In these circumstances there appears to be little role for the state, beyond enforcing contracts, keeping down barriers to entry, and resisting protectionist pressures. These considerations have lead some international trade economists (e.g. BHAGWATI 1968, BLACKHURST 1991) to argue that "open borders" can act as a substitute for national competition law and its enforcement.

Whether competition law and its enforcement has, in fact, contributed to securing the gains from international market integration is an empirical question upon which European experience in recent decades may be able to shed light. The study of motor vehicles may be particularly instructive in this regard as the production technology and organisational techniques in that industry provide a strong incentive to concentrate production in a limited number of locations. This implies that some countries will not produce cars and will be entirely dependent on imports to meet consumer needs. Formal state barriers on cars are de minimus within the European Economic Area (EEA), so in principle there are "open" borders in the international trade of motor vehicles. If open borders are so effective in disciplining market power within the EEA, then, actions by competition authorities in this sector should not be able to push prices down further towards incremental costs.

Other features of the commerce in motor vehicles, however, call into question this sanguine view of the effects of open borders. The desire of manufacturers that distributors of cars provide good pre-sale and post-sales service to customers provides a strong incentive for the former to influence the latter's behaviour, typically through the use of vertical private agreements. Manufacturers' interests, however, need not be confined to service improvements and the concern arises as to whether vertical agreements are used to restrict competition in motor vehicles between and within countries. These conflicting considerations suggest that the enforcement of competition law that seeks to promote the efficient allocation of resources treats vertical agreements on a rule of reason basis and that, in principle, competition au- 
thorities' actions could improve or (inadvertently) worsen customer welfare in markets where such agreements are found. Customer welfare may depend here on the quality of ancillary services as well as on prices, and arguably a comprehensive assessment of the effect of enforcement actions on consumer welfare would take changes in both factors (and any other relevant matters) into account. Practically speaking, however, the paucity of data on service quality tends to make the ideal assessment impossible. This does not detract from the broader point that although competition law can have a positive impact on consumer welfare in an era of open borders, it does not follow that competition law has had such an effect. The forgoing discussion implies that an evaluation of interventions by a competition authority in a European economy with low or no formal trade barriers may well shed light on significant policy matters going well beyond the industry in question. Moreover, to the extent that any evaluation reveals positive estimates of consumer welfare gains from competition law-based interventions, then those gains can be compared with the cost of the relevant competition authority, providing a sense of the value-for-money that that country's taxpayers gets from funding its competition law enforcement regime.

Using disaggregated data on the ten most popular models of car in Switzerland in the small-, medium-, and large-sized segments, the purpose of this paper is to examine whether the coming into force on 1 November 2002 of a Notice concerning vertical agreements in the motor vehicle trade, issued by the Swiss Competition Commission (COMCO/WEKO), had any effect on observed car price differences between Switzerland and its European trading partners in the years 2003 to 2006. Given the substantial mark-up in Switzerland on cars over the same models in bordering countries, which is also documented here, then if the Notice increased competition for customers in the Swiss automobile market then, other things being equal, one would expect to see the prices paid by Swiss consumers fall and the price differentials with other European nations on a model-by-model basis narrow. Alternatively, if after stripping out all of the variation caused by other factors, the Swiss-European price differentials for cars did not change, then it would be tempting to conclude that the Notice had no effect. The price response to the Notice's coming into force, then, may reveal the impact of a competition law measure in a sector with apparently open borders.

The subject matter in this paper is related to two streams of literature on international commerce and competition law. The first stream concerns the extent and determinants of international price discrimination in general 
(see Goldberg and KNETTER 1997 for a still relevant survey) and in automobiles in particular. With respect to the latter, the effect of trade barriers, exchange rate variation and regimes, and the so-called Block Exemption from European Community (EC) competition law has attracted much scholarly attention. Price dispersion in the European car market has been studied by Verboven (1996), Goldberg and Verboven (2001), Gil-Pareja (2003), and LUTZ (2004). From our purposes it is noteworthy that VERBOVEN (1996) argues that, on the basis of his empirical findings, that collusion between firms cannot be ruled out in Germany and the United Kingdom. Moreover, GIL-PAREJA (2003) presents evidence that suggests that the motor vehicle market was still segmented after the implementation of the Single Market programme from 1992. LuTz (2004) examines the determinants of car prices in Europe during 1993-1998 and finds some evidence of price convergence. LUTZ interprets his evidence as suggesting that transportation costs (as proxied in his study by distance) and consumer preferences for domestically-produced cars influenced price dispersion. In general, factors which facilitate arbitrage across markets, such as geographical proximity, shared languages, common borders, and common currencies, were found to have led to narrower price differentials. It is worth noting that many of these factors, including distance, are time-invariant and our empirical analysis will take account of this fact.

BREnKERs and Verboven (2006) examine the effect of liberalising EC rules on vertical restraints in the motor vehicle trade and argue that much depends on whether those restraints previously constrained competition between brands of cars within a country. If so, the elimination of these restraints were estimated to raise European Union (EU) consumer welfare between 16 and 22 percent. Taking producer welfare also into account, the overall welfare increase would be between $€ 9$ billion and $€ 11$ billion. If not, that is the restraints did not affect intra-brand competition, then the welfare gains were estimated to be positive and up to $€ 3$ billion. It is worth stating that the difference between BRENKERS and VERBOVEN's study and ours is that they examine the potential impact of the future liberalisation of a vertical restraint, whereas we examine the effect of a state measure taken in the past. Nevertheless, in principle, both studies might shed light on the impact of competition law measures in an era of open European borders.

This paper can also been seen in the light of the growing literature on assessing and estimating the effectiveness of actions taken by competition authorities. KOVACIC (2006) provides a comprehensive and illuminating overview of many facets of ex-post evaluations of the performance of com- 
petition law. BAKER (2003) and CRANDALL and WINSTON (2003) provide divergent views on the impact of United States (U.S.) antitrust (competition) enforcement, and WERDEN (2008) provides a later assessment of the evidence on the American experience. An important early quantitative and qualitative assessment of the enforcement of $\mathrm{EC}$ vertical restraints law can be found in Neven, Papandropolous, and Seabright (1998). Duso, NEVEN, and Roller (2007) use an event study methodology to compare stock-market and European Commission assessments of the effects of proposed mergers, finding substantial divergences between the two. BuCCIROssI et al. (2007) develop a methodology for ex-post assessments of European merger control decisions. The comparable literature on the impact of cartel enforcement is of longer standing see, for example, SPROUL (1992) for some negative findings.

Before proceeding it is worth stating that this study was conducted independently of the Swiss Competition Commission. While the authors had conversations with $\mathrm{COMCO} / \mathrm{WEKO}$ officials, rules on the disclosure of confidential business information substantially constrained the information that the COMCO/WEKO could disclose. As a result a substantial amount of effort was required by the authors to collect all of the price and quantity information for car transactions within Switzerland and within other EEA members. Moreover, the empirical strategy adopted by the authors was their choice. The strengths and weaknesses of the associated methodology and the resulting findings are, therefore, and any criticism of them should be directed towards the authors and not to the Swiss Competition Commission.

The remainder of this paper is organised into three sections. The next section discusses the 2002 Notice on vertical agreements in the motor vehicle trade issued by the COMCO/WEKO and other enforcement measures taken in this sector. Section three describes the empirical strategy employed in this paper, the data collected, the econometric estimation procedure used and its rationale, the estimation results and robustness checks performed, and the estimates of the consumer benefits that follow from the 2002 Notice coming into force. A discussion of this study's findings, including caveats, its implications and potential policy importance, is found in section four. 


\section{The Swiss competition authority and the Swiss market for motor vehicles}

The Swiss Competition Commission and its predecessor, the Kartellkommission, have long taken an interest in the terms upon which motor vehicles are sold in Switzerland. Nearly 15 years ago, for example, in 1994 the Kartellkommission issued a directive concerning the allowable contracts between car producers and merchants or distributors. Given the close alignment of Swiss competition law with comparable EC law, the WEKO and its predecessor have taken a number of measures that seek to ensure that the treatment of motor vehicle trade in Switzerland is close to that in the EU. The WEKO has also undertaken investigations of vertical agreements signed by specific automobile manufacturers. Volkswagen and Citroen were so investigated in 2002 and contents and impetus behind the WEKO Notice (that is the subject of much of this paper) may well have been influenced by these particular investigations. Although no sanctions were imposed in either case, Citroen did make a unilateral declaration that, henceforth, it would cease awarding exclusive territories in its contracts with distributors.

Despite these steps concerns about the high prices of cars in Switzerland relative to neighbouring countries persisted. There are, of course, legitimate reasons why the price of the same good may vary across neighbouring countries, and these may include differences in warranties, after sales service contracts, and taxes. One policy-relevant question, then, is whether the observed price differences reflect benign factors or those relating to anti-competitive practices. To provide some ideas of the magnitude of these international price differences in 2002, we collected data on the list prices of the ten best selling car models in the small-, medium-, and large-sized car segments. ${ }^{4}$ With the prices of the same models in France, Italy, and Germany, we were able to calculate model-by-model the price gap between Switzerland and these three neighbouring countries. Moreover, with sales data in Switzerland in 2002, we calculated the weighted average of the mark-up of Swiss prices for each segment of car market (small, medium, and large) and for the three neighbouring countries (France, Germany, and Italy.) These calculations netted out differences in tax treatment for cars across the respective jurisdictions and the results are reported in Table 1. The weighted average price mark-up for Swiss cars is always positive, typically lying between 10 and 20 percent above prices in neighbouring countries. The gap between Swiss and Italian car prices tends to be less than those between

4 All of the sources of data used in this study are described in detail in section 3.2. 
Swiss and French and Swiss and German car prices. Given the ease with which persons can travel around Europe and with which information can flow across borders, price differences of this magnitude on essentially like cars are likely to have been noticed by customers, newspapers, and other media and the associated discontent may well have motivated further action by the Swiss Competition Commission.

On 21 October 2002 the Swiss Competition Commission adopted a "Notice regarding the Competition Law Treatment of Vertical Agreements in the Motor Vehicle Trade." This Notice was issued under the powers granted to the WEKO by Article 6 of the Cartel Act. The Notice explicitly referred to the adoption on 31 July 2002 of EC Commission Regulation No. 1400 (2002) that concerned the application of EC competition law to vertical agreements and other selected practices in the motor vehicle sector (this regulation often being referred to as the Block Exemption Regulation.) The Notice goes on to state that:

"The Competition Commission thereby wishes to prevent price fixing and isolation of the Swiss market as well as to encourage internal market competition. It also wishes thereby to stimulate competition on the customer services market.”

The essence of this Notice is contained in section B on "Rules." That article states that agreements between motor vehicle suppliers and dealers that restrict competition cannot be justified on the grounds of enhancing economic efficiency if the restriction takes certain specified forms. The latter forms include: fixing the minimum or actual sales prices of the car dealer (Article 12 of the Notice), certain restrictions associated with exclusive distribution systems (Article 13), certain restrictions associated with a selective distribution system (Article 14), and six specific restrictions associated with customer service (Article 15). Restrictions on dealers selling more than one brand were not allowed (Article 16) as were certain circumstances upon which a dealers contract could be terminated (Article 17). The Notice is reproduced in full in the Annex to this paper.

This Notice came into force on 1 November 2002 although "existing distribution agreements in the motor vehicle trade are to be brought into line with this Notice prior to 1 January 2005" (according to Article 18(2)). The latter implies that the effect of this Notice may be felt in part in 2003 and 2004 and that, in principle, in full from 2005 on. Our empirical analysis will allow for the possibility that the effect on car prices may be partial-even zero-in the years before 2005 . 
Since this Notice was issued in 2002, the WEKO sought in 2004 to further elaborate its contents. Moreover, on 2 July 2007 the WEKO adopted a more general (that is not sector-specific) Notice concerning vertical agreements between firms. The latter Notice came into effect on 1 January 2008 and is unlikely to have affected the prices of cars studied in this paper (our analysis considers prices up to and including the year 2006). Finally, a review of WEKO's enforcement record during the years 2003 to 2006 revealed that no other measures were taken or investigations concerning the Swiss motor vehicle market were undertaken after the announcement of the 21 October 2002 Notice. Apart from any changes in tax treatment (that we will take care of in the empirical analysis that follows), then, the only significant policy regime change experienced in the Swiss car market was the coming into force of the 22 October 2002 Notice. ${ }^{5}$ Bearing in mind that the Notice may not have taken its full effect until 2005, we now describe the empirical strategy used to ascertain whether the 2002 Notice resulted in discernible changes in the degree to which Swiss car prices exceeded those of other European nations.

\section{An empirical analysis of the price-related effects of the 2002 WEKO Notice}

Using data on the prices of 30 models of car in Switzerland and in 12 other European nations over the years 1996-2006, the goal of our empirical strategy was, controlling for other potential determinants of cross-border price differences, to estimate the extent to which price discrimination against Swiss car buyers narrowed after the 2002 WEKO Notice came into force. In short, in the years after 2002 we used standard econometric tools to determine whether there were otherwise unaccounted reductions in international car price differentials. This analysis was performed separately for the 10 best selling small car models, the 10 best middle sized car models, and the 10 best large selling car models in Switzerland; thereby, allows for different potential findings across segments of the Swiss car market.

The literature on pricing-to-market and international price discrimination was consulted, along with the papers that examine the price dispersion of cars in Europe (referred to already in the introduction), for candidate in-

5 Of course, factors unrelated to policy may have influenced the Swiss car market (such as exchange rate changes, production cost increases of automobile manufacturers, changes in the price of petrol and in the demand for cars more generally.) Stripping out the effects of these market-related sources of price variation is one of the challenges that we take on in our empirical analysis. 
dependent or control variables. The theory of pricing the same good in multiple, segmented markets gives prominence to the roles that marginal costs of production and the own price elasticity of demand play in determining prices. Since cars are produced in one location and shipped to many other locations, some of which are abroad, then the variation in the relevant nominal exchange rates should also be taken into account. ${ }^{6}$ International transportation costs are another plausible determinant of price differences as are country-specific preferences for domestic or foreign produced cars. As will become clear later, some of these determinants are likely to be time invariant or common across all models in a given segment of the Swiss car market and the dependent variable in our analysis has been constructed in such a way as to eliminate these particular factors while still revealing potentially relevant information about changes in international price differences over time.

It will be useful to now introduce some notation. Let $m$ refer to a given model of car, $t$ to the year, $s$ to all variables relating to Switzerland, and $c$ to variables relating to another European economy. Denote $P_{j m}^{t}$ as the price paid by a purchaser of model $m$ in country $j(j=s, c)$ in year $t$. Further, note that the ratio of

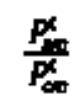

is a measure of the degree to which model $m$ is sold in year $t$ at a higher price in Switzerland as compared to another country, $c$. Note that if $P_{j m}^{t}$ is a multiplicative function of its determinants and one of those determinants is a time-specific model-invariant effect, then the natural logarithm,

$$
\text { in }\left(\frac{p i s}{p_{0}}\right)
$$

will not be a function of the latter effect. Likewise, in many theoretical formulations of international price discrimination across segmented markets, this natural logarithm will not be a function of the marginal cost of production (such costs affecting both the numerator and denominator equally, and therefore cancelling out.) Having said this, any time-invariant country-specific and country pair-specific effects will affect this ratio. Again assuming that the latter two effects enter multiplicatively into the expression for prices, then the following time-differenced measure of the change in international price discrimination will wash out (that is, eliminate) these two effects:

6 The considerable literature in international trade on exchange rate pass-through is devoted to estimating the extent to which export prices respond to nominal exchange rate variation. 


$$
D_{c m}^{t}=\ln \left(\frac{P_{s m}^{t}}{P_{c m}^{t}}\right)-\ln \left(\frac{P_{s m}^{t-1}}{P_{c m}^{t-1}}\right),
$$

where the subscript $s$ is dropped as the international price difference for each model in each year is always calculated with reference to Switzerland. The variable $D_{c m}^{t}$ is the dependent variable in our econometric analysis and varies across years $t$ (between 1996 and 2006, that is, 10 observations on year-to-year price differences $)^{7}$, across Switzerland's European trading partners $c$ (of which there are 12 in our sample), and car model $m$ (of which there are 10 models in each of the three segments of the Swiss car market that we examine.) Each sample, then, would comprise at most 1200 data points.

One determinant of prices that is not "washed out" by taking the ratio of prices of a given car model and by time-differencing is the nominal exchange rate. For this reason a variable comparable to $D_{c m}^{t}$ was constructed to measure nominal exchange rate variation. Denote $R_{s}^{t}$ as the nominal bilateral exchange rate of country c's currency with the Euro in year $t$ and $R_{s}^{t}$ as the Swiss Franc-Euro nominal exchange rate in year $t$. Then, define analogously to $D_{c m}^{t}$,

$$
E_{c}^{t}=\ln \left(\frac{R_{c}^{t}}{R_{s}^{t}}\right)-\ln \left(\frac{R_{c}^{t-1}}{R_{s}^{t-1}}\right)=\ln \left(\frac{R_{c}^{t}}{R_{c}^{t-1}}\right)-\ln \left(\frac{R_{s}^{t}}{R_{s}^{t-1}}\right) .
$$

A negative value of $E_{c}^{t}$ corresponds to the case where, between the years $(t-1)$ and $t$, the Swiss Franc is depreciating faster against the Euro than country c's currency. As is well known from theory, the effect of a depreciation of a nominal exchange rate on prices charged in segmented export markets can be negative or positive. Having said that, much empirical evidence points to a positive degree of pass-through of exchange rate variation to prices (Goldberg and KNetter 1997, StenneK and Verboven 2001).

A variable, comparable in construction to $D_{c m}^{t}$ and $E_{c}^{t}$, was constructed for differential rates of price inflation and is denoted $I_{c}^{t}$. Given that inflation rates are often a leading indicator of the stage of the business cycle (tending to rise during booms, fall during recessions), which may have implications for differences in the demand for cars across jurisdictions, then variable $I_{c}^{t}$ was also included as an additional determinant of international price differences of cars. Variable $I_{c}^{t}$ might best be thought of as affecting the differential willingness to pay for cars through the effect of inflation on national in-

7 It is important to note that in this study once a variable is in time-difference form then the index $\mathrm{t}$ refers to the annual difference between year $\mathrm{t}$ and year $(\mathrm{t}-1)$. This remark applies to the dependent variable and the time-varying independent variables. 
terest rates and, therefore, on cross-country differences in the availability of and terms for credit often needed to fund the purchases of cars.

\subsection{Data collected}

Since our goal was to examine whether there is any discrete change in the prices of cars sold in Switzerland after the 2002 WEKO Notice came into force, to provide a basis for comparison we deliberately constructed a dataset that included years before 2002. In fact, we chose to examine car prices over the period 1996 to 2006, the last year for which we could obtain car price data. We set about collecting such price data (so as to construct variable $\left.D_{c m}^{t}\right)$ and the corresponding exchange rate and inflation data for the same years (in turn to construct variables $E_{c}^{t}$ and $I_{c}^{t}$, respectively.)

Describing the sources of macroeconomic data is more straightforward and this is where we begin this account. Data on bilateral nominal exchange rates, including during the period before the Euro was formally launched, were collected from www.x-rates.com. The final bilateral rates used to convert the currencies of the members of the European Monetary Union (EMU) into Euros were employed to calculate the comparable bilateral exchange rate between a country c's currency and the Euro before the latter formally came into force for goods transactions in 1999. The intertemporal variation in the Swiss Franc compared to the Euro is graphed in Figure 1.

Data on consumer prices were taken from two sources. The Landesindex der Konsumentenpreise, compiled by the Swiss Bundesamt für Statistik, was taken as the price index for Switzerland. The harmonised index for consumer prices, collected by Eurostat and reported for each EU member state, was the source of the inflation data for the 12 Swiss trading partners included in this study. The 12 trading partners being Austria, Belgium, France, Germany, Ireland, Italy, Luxembourg, Netherlands, Portugal, Spain, Sweden, and the United Kingdom.

Before collecting car price data we had to decide which models or makes of car to include in the study. We took the motor vehicle industry's own classification of cars, which differentiates amongst others between small, medium, and large cars, and identified the 10 models in each of these three car segments that sold the most cars in Switzerland during 1996 to $2004 .^{8}$ For

8 Data on the quantity of cars sold came from an annual publication of the Bundesamt für Statistik. 
each of the 10 models and for each segment of the car market we then sought data on the prices they were sold at in Switzerland and in the 12 other European nations included in this study. Difficulties arise here because the tax treatment of cars varies across European nations and because dealers may offer different prices for the same model to different customers. Since we did not have access to transaction-specific price data (which is arguably the ideal) we sought information on the list prices of each model of car. In Switzerland the mid-February list price for each model is reported annually in the Katalog der Automobilrevue. We stripped out from these Swiss prices the full effect of the four percent import tariff on cars and the applicable value added tax (which has varied across the sample). Car prices in the EU have long been monitored by the Directorate-General for Competition which reports in national currencies the average list price of certain car models on 1 May in a given year. The European Commission's data strips out the effect of country-specific taxes.

With data on car prices, exchange rates, and consumer price indices, the variables $D_{c m}^{t}, E_{c}^{t}$ and $I_{c}^{t}$ were calculated. For each segment of the car market, the simple correlation coefficients between $D_{c m}^{t}$ and $E_{c}^{t}$ and between $D_{c m}^{t}$ and $I_{c}^{t}$ were calculated, and they are reported in Table 2. In each sample, there is a strong positive correlation between intertemporal changes in car price differences and the relative value of the Swiss franc. No such correlation exists between the relative price of Swiss cars and differential inflation rates.

In order to estimate the impact of any price reductions on Swiss consumer welfare, data is needed on the quantities of each of the 30 car models considered in this study. Collecting such data was no easy task as the Swiss Bundesamt für Statistik ceased publishing in 2004 its annual reports on the total number of each car model sold in Switzerland. Moreover, the industry association Auto-Schweiz only began reporting annual sales per car model in 2006. Car sales data was taken from both of these sources for the years 2003, 2004, and 2006. For 2005 we contacted the Swiss headquarters of the major Swiss car sellers and sought their data on car sales by make. Fortunately, all of the car sellers were forthcoming, enabling us to assemble comparable data for 2005. We, therefore, have data on the quantity of cars sold in Switzerland for four full years after the 2002 WEKO Notice came into effect.

Data on the operating costs of the Swiss Competition Commission for the years 2003 to 2006 were taken from the Rechnung of the Swiss Federal Government. Finally, estimates of the own price elasticity of demand for small, 
medium., and large cars were taken from BRENKERS and VERBOVEN (2006). The relevance of these last two pieces of information will become apparent in section 3.5 below.

\subsection{The base econometric specification employed}

The base specification employed in this study takes $D_{c m}^{t}$ as the dependent variable, controls for the variation created by exchange rate and consumer price inflation (using $E_{c}^{t}$ and $I_{c}^{t}$ ) and then examines if there is any year-onyear variation in international price difference that is common to all models in a given segment of the car market. If the 2002 WEKO Notice had a wideranging effect on the Swiss car market, bringing Swiss prices closer into line with its European trading partners, then this should manifest itself in some, or even all, the years after 2002 in level reductions in international price differences. The base specification introduces a set of time dummy variables that could capture this effect. Specifically the base specification employed is:

$$
\begin{aligned}
& D_{c m}^{t}=\beta_{0}+\beta_{1} I_{c}^{t}+\beta_{2} E_{c}^{t}+\sum_{j=1997}^{2006} \beta_{j} D V_{c m}^{t}+\varepsilon_{c m}^{t} \\
& \text { where } \quad D V_{c m}^{t}=\left\{\begin{array}{cc}
1 & t=j \\
0 & \text { otherwise }
\end{array}\right.
\end{aligned}
$$

and $\varepsilon_{c m}^{t}$ is a normally distributed error term. ${ }^{9}$

In addition to potentially finding that the estimates of $\beta_{j}(\mathrm{j}>2002)$ are statistically insignificant (which would suggest that the WEKO Notice had no effects on international price differentials), it is possible for any price decreases in the years just after the Notice came into effect to be reversed subsequently. Our approach, therefore, can also reveal whether the WEKO Notice had transitory or long-term effects on Swiss-EU car price differences.

Concerns about the influence of outliers led us to systematically trim five or 10 percent of each sample and report the estimated parameters for the trimmed and untrimmed samples. Concerns about heteroskedacity led us to estimate robust standard errors for each parameter. Therefore, ordinary least square techniques were used along with White-corrected standard errors. The estimation results for the base specification can be found in Table 3 .

9 Recall the remark made in footnote 7 about the interpretation of time index $t$. 


\subsection{Estimation results and robustness checks}

Examination of the information presented in Table 3 leads to the following remarks. First, in each car segment the inclusion of outliers substantially affects the estimated parameters, especially the dummy variables included to identify segment-specific cross-model intertemporal price changes. In contrast, the parameter estimates for the relative exchange rate variation is relatively unaffected by the inclusion of outliers. Given the sensitivity of ordinary least squares methods to the presence of outliers, we argue that the underlying determinants of the intertemporal changes of the great majority of car price differences are better revealed by the regressions where the samples have been trimmed. (Note that we trim each sample by five and 10 percent of the total number of observations, enabling readers to compare whether the degree of trimming affects the qualitative findings and conclusions drawn.)

Second, in the trimmed small car samples it is very difficult to make the case that after 2002 there was a narrowing of international car price differentials. While is it true that (at the 10 percent level of statistical significance in the sample where five percent of the sample was trimmed and at the five percent level of statistical significance in the sample where 10 percent of the same was trimmed) Swiss car prices moved toward EU levels between 2003 and 2004, the estimated parameter for the price change between 2002 and 2003 implies that such differences widened immediately after the Notice came into effect! Overall, then, there is not much evidence here of any discernible impact of the WEKO Notice on the prices paid by Swiss buyers of small cars.

Third, in contrast to the results for small cars, the parameters estimated for the trimmed samples relating to the medium and large car segments are consistent with a distinct break in pricing behaviour after 2002. In the case of medium-sized cars, when five percent of the original observations are trimmed it appears that the reductions in international car price differences during 2002-2004 are partially reversed in 2005-2006. However, further trimming of the sample reveals that the latter price reversal is not robust, suggesting that the WEKO Notice was followed by a distinct two-year narrowing of Swiss-EU car prices. The trimmed samples for the large car segment generate parameter estimates that imply international price differences for these cars narrowed during 2004 and 2005, suggesting that the price adjustment was delayed for the more expensive (larger) cars. Delaying 
compliance may well have had a greater payoff for manufacturers and distributors of larger cars than for medium-sized cars.

The fourth finding in Table 3 is that the relative consumer price inflation variable, which was thought to affect the demand for cars (through monetary policy and ultimately interest rates and the access to credit) did not statistically significantly influence Swiss-EU car price differences. Even so, the inclusion of this independent variable does represent an attempt to control for differences in the stage of the business cycle across countries in this sample.

Our next steps was to involved examininge how robust the above qualitative findings were to perturbations from the base specification. One alternative specification, motivated by an approach taken in some of the passthrough literature that allows for asymmetric responses of prices to either costs or exchange rate increases and decreases, was to estimate a separate parameters for the cases where $E_{c}^{t}$ rose and when $E_{c}^{t}$ fell. This alternative specification did not alter the qualitative findings reported above ${ }^{10}$ but did imply a slightly smaller post-2002 narrowing of international price differentials for larger cars.

We also considered a different formulation that might reveal a break in post-2002 Swiss-EU car price differences. Rather than estimate a dummy variable for each year-on-year difference, we included a time trend that only took a positive value after 2002, the year when the WEKO Notice was promulgated. The parameter estimate on this post-2002 trend term, denoted $\beta T$, could be thought of as revealing the annual average price change after the WEKO Notice was announced. The estimates of $\beta^{T}$ in each car segment are reported in Table 4 for the samples where five percent of the observations have been trimmed. The estimates in Table 4, qualitatively speaking, reinforce the findings from the base specification, in particular as they relate to the medium-sized and large-sized car segments. Although we will err on the side of caution, and in so doing prefer the more conservative findings in Table 3, we recognise that a more aggressive interpretation of the parameter estimate of $\beta^{T}$ for the impact of the WEKO Notice on Swiss-EU price differentials of small cars is possible. That more aggressive interpretation would point to an annual decrease in such car price differentials of approximately 0.9 percent per year.

10 For this reason the full set of estimated parameters are not reported towards the end of this paper. 
In sum, then, our econometric analysis of Swiss-EU car price differences resulted in parameters being estimated that cannot reject the proposition that the WEKO 2002 Notice on vertical agreements in the motor vehicle sector led to non-transitory reductions in such price differences in the mediumsized and large-sized car segments. We now turn to estimates of the effects of these reductions on Swiss consumer welfare and compare those estimates with the cost of running the Swiss Competition Commission.

\subsection{Estimates of the consumer benefit from the 2002 WEKO Notice}

The parameter estimated using the base specification on the trimmed samples of data on medium-sized and large-sized cars, reported in Table 3, imply that in total Swiss-EU car price differences fell approximately $4.2 \%$ and $6.6 \%$, respectively, in the years after the WEKO Notice came into effect on 1 November 2002. ${ }^{11}$ In principle, these price differences could have been narrowed by raising prices charged for cars outside of Switzerland, in which case the prices paid by Swiss consumers would remain unchanged and there would be no effect on Swiss welfare. We discount this logical possibility on the following two grounds. First, car manufacturers and sellers would not have brought themselves into compliance with the WEKO Notice (through any necessary contractual changes with Swiss car distributors) by raising car prices outside of Switzerland. Even so, deliberately narrowing international price differences for cars might conceivably reduce public criticism of high Swiss car prices. Second, given the relatively small size of the Swiss car market compared to those found in certain EU member states (including France, Germany, and Italy, that border Switzerland), it seems implausible that car manufacturers would be willing to forgo profits ${ }^{12}$ in larger EU markets so as to limit or avoid competition law enforcement action in Switzerland. For this reason, we find the argument that car manufacturers altered their contractual arrangements with Swiss dealers and distributors which resulted in lower car prices a more plausible explanation for the narrowing of Swiss-EU automobile price differences after 2002. The following calculations are predicated, then, on the assumption that the entire price adjustment took place in Switzerland.

11 Using data on car prices and sales for the medium-sized and large-sized car models considered in this study, the cumulative effect of the price reductions amounted in 2006 to, on average, 929 Swiss Francs on a medium-sized car and 2113 Swiss Francs on a large-sized car.

12 As would be entailed by raising prices about levels that the car manufacturers thought were optimal for the EU market in the absence of the WEKO Notice and potential further enforcement action by the Swiss Competition Commission. 
A complete analysis of the effects on Swiss consumer welfare would take into account the reduced prices of all models in a particular segment of the car market, plus the falling prices in other car segments (where relevant.) $)^{13}$ We were unable to obtain or find estimates of the relevant cross-price elasticities of demand and so concentrated on the effects of own price reductions on Swiss consumer welfare. We shall, therefore, estimate how much lower Swiss consumer welfare would have been in the absence of the 2002 WEKO Notice. Given our base specification found no statistically significant reduction in EU-Swiss price differences in the small car market, what follows relates only to the medium-sized and large-sized car market.

Reference to Figure 2 may help explain the consumer welfare effect of the 2002 WEKO Notice for a given model of car. In the absence of the Notice the price of each make of car would have been higher, resulting in more cars being bought. The counterfactual reduction in quantity demanded also depends on the own price elasticity of demand and on the observed level of sales (when the Notice was in effect.) As noted in section 3.2. the latter two pieces of information were collected for this study ${ }^{14}$ and the estimated price changes in the absence of the WEKO Notice can be inferred from the parameter estimates reported in Table 3. With these three pieces of information it is possible to calculate the loss in Swiss consumer surplus in the absence of the WEKO Notice. Moreover, we can calculate not only the point estimate (or best estimate) of the change in Swiss consumer welfare but also the 95 percent lower bound. There is, therefore, a 95 percent probability that the actual consumer surplus change from implementing the 2002 WEKO Notice equals or exceeds this lower bound. In effect, this lower bound is a very conservative estimate of the benefits of the WEKO's action and likely represents a substantial under-estimate of the true benefit. Table 4 reports these calculations for the years 2003-2006 in current year (that is, 2008) Swiss Francs.

Given the estimated effect on prices of the WEKO decision was not apparent until 2004 for the large car segment, and that both medium-sized and

13 For completeness sake it should be stated that we do not take into account any effects of the WEKO Notice on the after sales service, warranties, etc, that might be offered by Swiss car distributors. Nor do we consider changes in the physical characteristics of the cars (e.g. model upgrades) that may have followed the introduction of the WEKO Notice that, in principle, can affect car prices. Taking account of both of these factors would require substantially more data that was collected for this study (and one might bear in mind the extensive efforts gone to collect the price and quantity data for this study in the first place.) To the extent that dealers offer different warranties and after-sales service, the data requirements needed to satisfactorily take into account the first of these two matters are particularly demanding.

14 Although it should be noted that the own price elasticities of demand reported in BRENKERS and VERBOVEn (2006) are estimates and, therefore, their true values are not known with certainty. 
large-sized cars both experience non-transitory level reductions in international price differentials, it follows that the Swiss consumer gains are felt in full in 2005 and 2006. The best (point) estimate of the total cumulative consumer welfare gain from the WEKO Notice coming into force exceeds a quarter of a billion Swiss Francs. Moreover, in 2006 the best estimate of the benefit to consumers was just under 95 million Swiss Francs.

The lower bound estimates of the gains to Swiss consumers, that take into account any covariance in the estimated narrowing in car price differentials, point to a total gain during 2003 to 2006 that exceeded 188 million Swiss Francs, of which the gain in 2006 alone was more than 75 million Swiss Francs. To put these numbers into some perspective, it is worth noting that the Swiss consumer gain in 2006 was ten times the WEKO budget for that year (7.3 million Swiss Francs in 2008 prices). Should the quantity of cars sold and their prices in Switzerland remain approximately at their $2006 \mathrm{lev}$ els, then consumers gains of this magnitude will recur and by implication Swiss taxpayers are getting a substantial return on their outlays on the Swiss Competition Commission. Moreover, given that tens of thousands of cars are sold every year in Switzerland these gains are likely to be widely spread among Swiss residents.

\section{Concluding remarks}

Although motivated by broader considerations, not least the desire to add to the small but growing literature on the costs and benefits of the actions taken by competition authorities in economies that are ostensibly open to international commerce, the empirical question at the heart of this paper is whether Swiss-EU car price differentials narrowed permanently after a Notice, relating to the vertical agreements between car manufacturers and their distributors, issued by the Swiss Competition Commission came into effect in November 2002. As is the case in many empirical studies using both disaggregated and cross-country data, a number of caveats arise and in the foregoing sections every attempt has been made to identify them. Those caveats and any concerns they raise should be kept in mind when drawing implications from this analysis.

Econometric evidence was presented in this paper that showed non-transitory and statistically significant reductions in Swiss-EU price differentials occurred in medium-sized and larger cars, but not in small-sized cars, after the WEKO Notice came into force. Moreover, whether viewed on an annual 
basis or cumulatively, the narrowing of these price differentials has produced benefits to Swiss purchasers of cars that are multiples of the governmental outlay on the Swiss Competition Commission. Given the avowed purpose of much competition law is to enhance customer welfare, the evidence in this paper suggests that in its actions in the motor vehicle market the Swiss Competition Commission has delivered substantial "value for money" for Swiss taxpayers.

Some economic observers may prefer a total welfare standard, rather than the consumer welfare standard employed in this paper and, as noted above, pursued by many competition authorities. This is a perfectly legitimate point but it is worth bearing in mind that the choice of welfare standard used for policymaking is an ethical one and that, however compelling to some, this matter cannot be resolved by appeal to microeconomic first principles alone. Nevertheless, it is true that some of the consumer gains estimated here are transfers from car distributors (and possibly manufacturers). Our best estimate of the consumer gains that arose solely because more transactions took place following the Swiss Competition Commission's actions - in other words our best point estimate of increase in total surplus created by the WEKO's actions - is over 42 million Swiss Francs for the years 2003-2006, an amount that far exceeds the WEKO's budget for those four years. Moreover in 2006, by which time the price effects of the WEKO Notice had worked through fully, the total surplus created in that year alone was just under 18 million Swiss Francs, more than twice the annual cost of the WEKO.$^{15}$ Whether a consumer or total welfare standard is used does not materially affect the conclusion that expenditure on the WEKO represents good value for money for Swiss taxpayers.

The empirical findings in this paper have another important policy implication and this relates to the necessity of enacting competition laws in open economies in the first place. Some have contended that liberal trade and investment regimes can fully substitute for competition law, implying that the latter is unnecessary and public expenditures on such laws a waste of resources. This perspective ignores that fact that some firms have a strong incentive to segment markets along national lines and can employ vertical agreements with distributors to that end. Had our empirical analysis shown that Swiss-EU car price differentials were unaffected by the 2002 WEKO Notice then one could not reject the contention that cross-border competi-

15 Our most conservative estimates corresponding to the cumulative and annual total surplus gains exceed 24'245'276 and 10'997'191 Swiss Francs, respectively. 
tion undermines the viability of such a market segmentation strategy and, therefore, that banning vertical agreements is unnecessary. Instead, our analysis showed that state intervention to alter the set of permissible vertical agreements was followed by a narrowing of cross-border price differences, suggesting that competitive pressure intensified after the intervention and, therefore, that such pressure was somewhat stymied beforehand. Perhaps the right policy advice, then, is that sometimes liberal trade and investment regimes tackle anti-competitive practices and market power (our evidence on the small car market is not inconsistent with this interpretation) and sometimes they don't, in which case appropriately enforced competition law can make a contribution.

It would also be wrong to dismiss this evidence presented in this paper as necessarily particular to Switzerland. Like many jurisdictions, both developing and industrialised, only in recent years the ten years or so has Switzerland strengthened its competition law and enforcement regime, this taking place during an era of greater international market integration. Future research may well wish to examine whether countries in similar circumstances to Switzerland have had the gains from globalisation and market reforms in particular reduced through anti-competitive practices engendered by certain inter-firm agreements, including vertical agreements between suppliers, manufacturers, and distributors. 


\section{References to academic literature}

BAKER, JONATHAN B. (2003), “The case for antitrust enforcement," Journal of Economic Perspectives, vol. 17 (Fall) (4), pages 3-26.

Bhagwati, Jagdish N. (1968), The Theory and Practice of Commercial Policy, Princeton, N.J.: International Finance Section, Dept. of Economics, Princeton University.

Blackhurst, Richard (1991), "Trade Policy is Competition Policy," Competition and Economic Development, pages 253-257. Paper prepared for the OECD. Paris, France.

Brenkers, Randy and Frank Verboven (2006). "Liberalizing A Distribution System: The European Car Market," Journal of the European Economic Association, MIT Press, vol. 4(1), pages 216-251.

Buccirossi, Paolo, Lorenzo Ciari, Tomaso Duso, Sven-Olof Fridolfsson, Giancarlo Spagnolo and Cristiana Vitale (2007), "Ex-post Review of Merger Control Decisions - A study for the European Commission prepared by Lear."

Connor, John M. (2006), Global Price Fixing, Second Edition, Berlin: Springer.

Crandall Robert W. and Clifford Winston (2003), "Does Antitrust Policy Improve Consumer Welfare? Assessing the Evidence," Journal of Economic Perspectives, vol. 17 (Fall) (4).), pages 3-26.

Duso, Tomaso, Damien J. Neven and Lars-Hendrik Röller (2007). “The Political Economy of European Merger Control: Evidence Using Stock Market Data," The Journal of Law and Economics, vol. 50(3), pages 455-489.

Gil-Pareja, SAlvador (2003), "Pricing to market behaviour in European car markets," European Economic Review, Elsevier, vol. 47(6), pages 945-962, December.

Goldberg, Pinelopi K. and Michael M. Knetter (1997). "Goods prices and exchange rates: what have we learned?" Journal of Economic Literature. XXXV, vol. 35(3), pages 1243-1272.

Goldberg, Pinelopi K. and Frank Verboven (2005), "Market integration and convergence to the Law of One Price: evidence from the European car market," Journal of International Economics, Elsevier, vol. 65(1), pages 49-73, January.

Kovacic, William E. (20062), "Using Ex Post Evaluations to Improve the Performance of Competition Policy Authorities," Journal of Corporation Law, vol. 31(2), 503. 
Lutz, MatThias (2004). "Pricing in segmented markets, arbitrage barriers and the law of one price," Review of International Economics, vol. 12(3), pages 456-475.

Neven, Damien, Penelope Papandopolous and Paul Seabright (1998). Trawling for Minnows: European Competition Policy and Agreements Between Firms, London: CEPR. London.

Sproul, Michael F. (1993), "Antitrust and Prices," Journal of Political Economy, vol. 101(4), pages 741-754.

Stennek Johan and Frank Verboven (2001), "Merger Control and Enterprise Competitiveness: Empirical Analysis and Policy Recommendations." Study prepared for the European Commission, (2001). This study was subsequently published in a chapter (with the same title) of the following edited volume: ILZKOvitz FABIENNE and RoDERICK MEIKLEJOHN (2006 eds), European Merger Control: Do We Need An Efficiency Defence?, Edward Elgar Publishers, Cheltenham, United Kingdom (2006).

Verboven, Frank (1996), "International Price Discrimination in the European Car Market," RAND Journal of Economics, The RAND Corporation, vol. 27(2), pages 240-268, Summer.

Werden, Gregory (20087), "Assessing the effects of antitrust enforcement in the United States". Conference paper De Economist. December 2008, Volume 156, Issue 4, pages 433-451. 


\section{Tables and Figures}

Table 1: Sales-weight average percent mark up of prices for the same model of car in Switzerland over France, Italy, and Germany in 2002, by car segment and net of tax differences

\begin{tabular}{|l|c|c|c|}
\hline Car segment & France & Italy & Germany \\
\hline Small cars & $15.2 \%$ & $9.2 \%$ & $29.9 \%$ \\
\hline Medium cars & $20.0 \%$ & $14.6 \%$ & $19.9 \%$ \\
\hline Large cars & $18.9 \%$ & $12.0 \%$ & $15.1 \%$ \\
\hline
\end{tabular}

Table 2: $\quad$ Simple correlation coefficients between the time-varying variables

\begin{tabular}{|c|c|c|c|c|c|}
\hline Car segment & \multicolumn{3}{|c|}{$\begin{array}{c}\text { Simple correlation coefficient } \\
\text { between dependant variable } \\
\text { and } \operatorname{Ln}(\mathrm{E}) \text {, the exchange rate } \\
\text { variable. }\end{array}$} & \multicolumn{2}{|c|}{$\begin{array}{c}\text { Simple correlation coefficient } \\
\text { between dependant variable } \\
\text { and } \operatorname{Ln}(\mathrm{I}) \text {, the inflation } \\
\text { variable. }\end{array}$} \\
\hline Small cars & \multicolumn{3}{|c|}{0.458} & & $\begin{array}{l}-0.068 \\
-0.06\end{array}$ \\
\hline Medium cars & \multicolumn{3}{|c|}{0.532} & & -0.059 \\
\hline Large cars & \multicolumn{3}{|c|}{0.477} & & 0.052 \\
\hline \multirow[t]{2}{*}{ Car segment } & \multicolumn{4}{|c|}{$\begin{array}{c}\text { Simple correlation coefficient between } \\
\text { dependant variable and } \operatorname{Ln}(\mathrm{E}), \text { the } \\
\text { exchange rate variable. }\end{array}$} & \multirow{2}{*}{$\begin{array}{l}\text { Simple correlation } \\
\text { coefficient between } \\
\text { dependant variable and } \\
\text { Ln(I), the inflation } \\
\text { variable. }\end{array}$} \\
\hline & All data & $\operatorname{Ln}(\mathrm{E})>0$ & \multicolumn{2}{|c|}{$\operatorname{Ln}(\mathrm{E})<0$} & \\
\hline Small cars & 0.458 & 0.290 & 0.27 & & -0.068 \\
\hline Medium cars & 0.532 & 0.386 & 0.37 & & -0.059 \\
\hline Large cars & 0.477 & 0.223 & 0.39 & & 0.052 \\
\hline
\end{tabular}

Figure 1: Swiss Franc-Euro variation over time

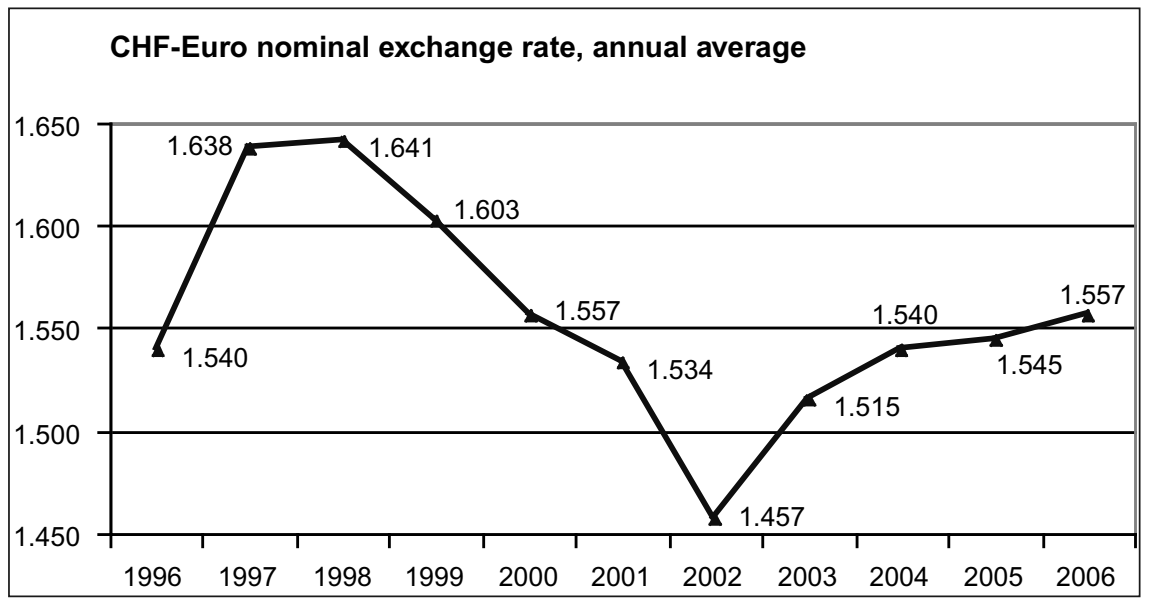


Table 3: Estimation results for preferred specification with annual estimates of the level price changes

\begin{tabular}{|c|c|c|c|c|c|c|c|c|c|}
\hline \multirow{2}{*}{$\begin{array}{l}\text { Parameter } \\
\text { estimates } \\
\text { and } \\
\text { summary } \\
\text { statistics }\end{array}$} & \multicolumn{3}{|c|}{$\begin{array}{l}\text { Small car segment: } \\
\text { Parameter estimate (p- } \\
\text { value), by sample }\end{array}$} & \multicolumn{3}{|c|}{$\begin{array}{c}\text { Medium car segment: } \\
\text { Parameter estimate (p- } \\
\text { value), by sample }\end{array}$} & \multicolumn{3}{|c|}{$\begin{array}{l}\text { Large car segment: } \\
\text { Parameter estimate (p- } \\
\text { value), by sample }\end{array}$} \\
\hline & $\begin{array}{c}\text { Full } \\
\text { sample }\end{array}$ & $\begin{array}{l}5 \% \\
\text { trim } \\
\end{array}$ & $\begin{array}{l}10 \% \\
\text { trim }\end{array}$ & $\begin{array}{c}\text { Full } \\
\text { sample }\end{array}$ & $\begin{array}{l}5 \% \\
\text { trim } \\
\end{array}$ & $\begin{array}{l}10 \% \\
\text { trim }\end{array}$ & $\begin{array}{c}\text { Full } \\
\text { sample }\end{array}$ & $\begin{array}{l}5 \% \\
\text { trim } \\
\end{array}$ & $\begin{array}{l}10 \% \\
\text { trim }\end{array}$ \\
\hline Constant & $\begin{array}{l}-0.047 \\
(0.000)\end{array}$ & $\begin{array}{l}-0.031 \\
(0.002)\end{array}$ & $\begin{array}{l}-0.027 \\
(0.008)\end{array}$ & $\begin{array}{l}-0.019 \\
(0.009)\end{array}$ & \begin{tabular}{|c|}
-0.002 \\
$(0.802)$ \\
\end{tabular} & $\begin{array}{l}-0.042 \\
(0.700)\end{array}$ & $\begin{array}{l}-0.006 \\
(0.343)\end{array}$ & \begin{tabular}{|c|}
0.002 \\
$(0.973)$ \\
\end{tabular} & $\begin{array}{c}0.006 \\
(0.363) \\
\end{array}$ \\
\hline $\operatorname{Ln}(\mathrm{I})$ & $\begin{array}{c}0.114 \\
(0.602)\end{array}$ & $\begin{array}{c}0.239 \\
(0.440)\end{array}$ & $\begin{array}{c}0.084 \\
(0.748)\end{array}$ & $\begin{array}{c}0.202 \\
(0.476)\end{array}$ & \begin{tabular}{|c|}
0.288 \\
$(0.223)$ \\
\end{tabular} & $\begin{array}{c}0.197 \\
(0.208)\end{array}$ & $\begin{array}{c}0.179 \\
(0.565)\end{array}$ & $\begin{array}{c}0.011 \\
(0.955) \\
\end{array}$ & $\begin{array}{c}0.065 \\
(0.707) \\
\end{array}$ \\
\hline $\operatorname{Ln}(E)$ & $\begin{array}{c}1.034 \\
(0.000) \\
\end{array}$ & $\begin{array}{c}1.088 \\
(0.000) \\
\end{array}$ & $\begin{array}{c}1.102 \\
(0.000) \\
\end{array}$ & $\begin{array}{c}1.054 \\
(0.000) \\
\end{array}$ & \begin{tabular}{|c|}
1.058 \\
$(0.000)$ \\
\end{tabular} & $\begin{array}{c}1.042 \\
(0.000) \\
\end{array}$ & $\begin{array}{c}0.919 \\
(0.000) \\
\end{array}$ & \begin{tabular}{|c|}
0.964 \\
$(0.000)$ \\
\end{tabular} & $\begin{array}{c}1.002 \\
(0.000) \\
\end{array}$ \\
\hline $\begin{array}{l}\text { 1997-8 } \\
\text { dummy, } \quad 1998 \\
\end{array}$ & $\begin{array}{l}0.0778 \\
(0.000) \\
\end{array}$ & $\begin{array}{c}0.054 \\
(0.000) \\
\end{array}$ & $\begin{array}{c}0.048 \\
(0.000) \\
\end{array}$ & $\begin{array}{c}0.048 \\
(0.000) \\
\end{array}$ & \begin{tabular}{|c|}
0.025 \\
$(0.051)$ \\
\end{tabular} & $\begin{array}{c}0.026 \\
(0.045) \\
\end{array}$ & $\begin{array}{l}-0.003 \\
(0.830) \\
\end{array}$ & \begin{tabular}{|l|}
-0.011 \\
$(0.087)$ \\
\end{tabular} & $\begin{array}{l}-0.019 \\
(0.002) \\
\end{array}$ \\
\hline $\begin{array}{l}1998-9 \\
\text { dummy, } 1999\end{array}$ & $\begin{array}{c}0.284 \\
(0.088) \\
\end{array}$ & $\begin{array}{c}0.033 \\
(0.779) \\
\end{array}$ & $\begin{array}{l}-0.004 \\
(0.728) \\
\end{array}$ & $\begin{array}{l}-0.001 \\
(0.895) \\
\end{array}$ & \begin{tabular}{|c|}
-0.012 \\
$(0.368)$ \\
\end{tabular} & $\begin{array}{l}-0.012 \\
(0.341) \\
\end{array}$ & $\begin{array}{c}0.032 \\
(0.002) \\
\end{array}$ & \begin{tabular}{|c|}
0.023 \\
$(0.000)$ \\
\end{tabular} & $\begin{array}{c}0.014 \\
(0.033) \\
\end{array}$ \\
\hline $\begin{array}{l}\text { 1999-2000 } \\
\text { dummy, } 2000\end{array}$ & $\begin{array}{c}0.066 \\
(0.000) \\
\end{array}$ & $\begin{array}{c}0.049 \\
(0.000) \\
\end{array}$ & $\begin{array}{c}0.032 \\
(0.008) \\
\end{array}$ & $\begin{array}{c}0.026 \\
(0.007) \\
\end{array}$ & \begin{tabular}{|c|}
0.015 \\
$(0.122)$ \\
\end{tabular} & $\begin{array}{c}0.012 \\
(0.286) \\
\end{array}$ & $\begin{array}{l}-0.017 \\
(0.128) \\
\end{array}$ & \begin{tabular}{|c|}
-0.025 \\
$(0.000)$ \\
\end{tabular} & $\begin{array}{l}-0.033 \\
(0.000) \\
\end{array}$ \\
\hline $\begin{array}{l}2000-1 \\
\text { dummy, } 2001\end{array}$ & $\begin{array}{c}0.035 \\
(0.009) \\
\end{array}$ & $\begin{array}{c}0.021 \\
(0.077) \\
\end{array}$ & $\begin{array}{c}0.006 \\
(0.539) \\
\end{array}$ & $\begin{array}{c}0.016 \\
(0.294) \\
\end{array}$ & \begin{tabular}{|c|}
0.010 \\
$(0.328)$ \\
\end{tabular} & $\begin{array}{c}0.003 \\
(0.723) \\
\end{array}$ & $\begin{array}{c}0.005 \\
(0.453) \\
\end{array}$ & \begin{tabular}{|c|}
0.015 \\
$(0.035)$ \\
\end{tabular} & $\begin{array}{l}-0.011 \\
(0.157) \\
\end{array}$ \\
\hline $\begin{array}{l}2001-2 \\
\text { dummy, } 2002\end{array}$ & $\begin{array}{c}0.037 \\
(0.052) \\
\end{array}$ & $\begin{array}{c}0.023 \\
(0.071)\end{array}$ & $\begin{array}{c}0.017 \\
(0.101)\end{array}$ & $\begin{array}{c}0.034 \\
(0.002)\end{array}$ & \begin{tabular}{|c|}
0.007 \\
$(0.536)$ \\
\end{tabular} & $\begin{array}{c}0.009 \\
(0.445)\end{array}$ & $\begin{array}{l}-0.035 \\
(0.010)\end{array}$ & \begin{tabular}{|l|}
-0.041 \\
$(0.001)$ \\
\end{tabular} & $\begin{array}{l}-0.050 \\
(0.000) \\
\end{array}$ \\
\hline $\begin{array}{l}2002-3 \\
\text { dummy, } 2003\end{array}$ & $\begin{array}{c}0.067 \\
(0.000) \\
\end{array}$ & $\begin{array}{c}0.053 \\
(0.000) \\
\end{array}$ & $\begin{array}{c}0.042 \\
(0.000)\end{array}$ & $\begin{array}{l}-0.001 \\
(0.874)\end{array}$ & \begin{tabular}{|c|}
-0.014 \\
$(0.084)$ \\
\end{tabular} & $\begin{array}{l}-0.014 \\
(0.071)\end{array}$ & $\begin{array}{c}0.009 \\
(0.293) \\
\end{array}$ & \begin{tabular}{|c|}
0.001 \\
$(0.877)$ \\
\end{tabular} & $\begin{array}{l}-0.000 \\
(0.983) \\
\end{array}$ \\
\hline $\begin{array}{l}2003-4 \\
\text { dummy, } 2004\end{array}$ & $\begin{array}{c}0.019 \\
(0.841)\end{array}$ & $\begin{array}{l}-0.149 \\
(0.097)\end{array}$ & $\begin{array}{l}-0.019 \\
(0.043)\end{array}$ & $\begin{array}{l}-0.014 \\
(0.093)\end{array}$ & \begin{tabular}{|l|}
-0.027 \\
$(0.026)$ \\
\end{tabular} & $\begin{array}{l}-0.026 \\
(0.044)\end{array}$ & $\begin{array}{l}-0.022 \\
(0.029)\end{array}$ & \begin{tabular}{|c|}
-0.022 \\
$(0.011)$ \\
\end{tabular} & $\begin{array}{l}-0.031 \\
(0.001) \\
\end{array}$ \\
\hline $\begin{array}{l}2004-5 \\
\text { dummy, 2005 }\end{array}$ & $\begin{array}{c}0.031 \\
(0.012) \\
\end{array}$ & $\begin{array}{c}0.016 \\
(0.071) \\
\end{array}$ & $\begin{array}{c}0.011 \\
(0.233) \\
\end{array}$ & $\begin{array}{c}0.003 \\
(0.764) \\
\end{array}$ & \begin{tabular}{|c|}
0.002 \\
$(0.846)$ \\
\end{tabular} & $\begin{array}{c}0.007 \\
(0.580) \\
\end{array}$ & $\begin{array}{l}-0.035 \\
(0.000)\end{array}$ & \begin{tabular}{|c|}
-0.042 \\
$(0.000)$ \\
\end{tabular} & $\begin{array}{l}-0.042 \\
(0.000) \\
\end{array}$ \\
\hline $\begin{array}{l}2005-6 \\
\text { dummy, } 2006 \\
\end{array}$ & $\begin{array}{c}0.051 \\
(0.000) \\
\end{array}$ & $\begin{array}{c}0.029 \\
(0.018) \\
\end{array}$ & $\begin{array}{c}0.013 \\
(0.169) \\
\end{array}$ & $\begin{array}{c}0.032 \\
(0.001) \\
\end{array}$ & \begin{tabular}{|l|}
-0.018 \\
$(0.056)$ \\
\end{tabular} & $\begin{array}{c}0.014 \\
(0.206) \\
\end{array}$ & $\begin{array}{c}0.015 \\
(0.049) \\
\end{array}$ & $\begin{array}{c}0.008 \\
(0.955) \\
\end{array}$ & $\begin{array}{c}0.004 \\
(0.534) \\
\end{array}$ \\
\hline $\begin{array}{l}\text { Number of } \\
\text { observations } \\
\text { in sample }\end{array}$ & 905 & 859 & 815 & 1056 & 1004 & 950 & 962 & 914 & 866 \\
\hline $\mathrm{R}^{2}$ & 0.274 & 0.351 & 0.394 & 0.319 & 0.398 & 0.459 & 0.303 & 0.401 & 0.459 \\
\hline
\end{tabular}

Table 4: Estimation results for preferred specification with annual estimates of the level price changes

\begin{tabular}{|l|c|c|c|}
\hline \multirow{2}{*}{$\begin{array}{l}\text { Parameter estimates } \\
\text { and summary } \\
\text { statistics }\end{array}$} & \multicolumn{3}{|c|}{$\begin{array}{c}\text { Sample after trimming 5\% outliers: } \\
\text { Parameter estimate (p-value), by sample }\end{array}$} \\
\cline { 2 - 4 } & Small cars & Medium cars & Large cars \\
\hline Constant & $-0.1066(0.123)$ & $-0.0009(0.862)$ & $-0.0032(0.247)$ \\
\hline Ln(I) & $-0.2575(0.256)$ & $-0.1621(0.369)$ & $0.1117(0.323)$ \\
\hline Ln(E) & $1.0905(0.000)$ & $1.1016(0.000)$ & $0.8894(0.000)$ \\
\hline $\begin{array}{l}\text { Post 2002 annual } \\
\text { dummy, T }\end{array}$ & $-0.0091(0.062)$ & $-0.0124(0.008)$ & $-0.0100(0.018)$ \\
\hline \hline $\begin{array}{l}\text { Number of } \\
\text { observations in } \\
\text { sample }\end{array}$ & 859 & 1004 & 914 \\
\hline $\mathrm{R}^{2}$ & 0.2822 & 0.3660 & 0.3068 \\
\hline
\end{tabular}


Figure 2: The consumer welfare loss from higher prices of imported cars.

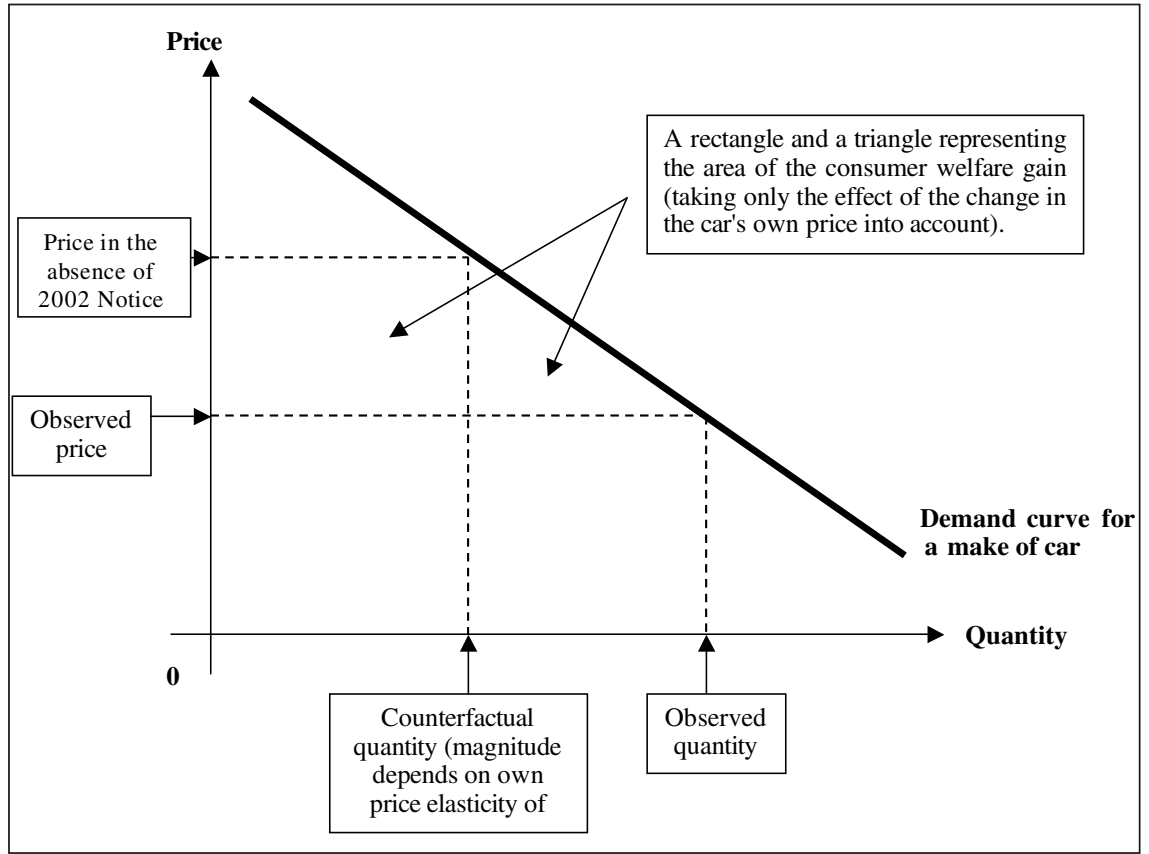

Table 5: Estimates of the benefits to Swiss car buyers of the WEKO Notice, measured in 2008 Swiss Francs

\begin{tabular}{|c|c|c|c|c|}
\hline Year & $\begin{array}{c}\text { Car } \\
\text { segment }\end{array}$ & $\begin{array}{l}\text { Best estimate of the } \\
\text { benefits to Swiss car } \\
\text { buyers, CHF. }\end{array}$ & $\begin{array}{l}\text { Most conservative } \\
\text { estimate of the } \\
\text { benefits to Swiss car } \\
\text { buyers, CHF. }\end{array}$ & $\begin{array}{c}\text { Total budget of } \\
\text { WEKO in the given } \\
\text { year, CHF. }\end{array}$ \\
\hline 2003 & $\begin{array}{l}\text { Medium } \\
\text { Large }\end{array}$ & $\begin{array}{c}14^{\prime} 436^{\prime} 461 \\
0\end{array}$ & $\begin{array}{c}2^{\prime} 007^{\prime} 822 \\
0\end{array}$ & 7'447'725 \\
\hline 2004 & $\begin{array}{c}\text { Medium } \\
\text { Large }\end{array}$ & $\begin{array}{l}38^{\prime} 681 ' 254 \\
21^{\prime} 718^{\prime} 235\end{array}$ & $\begin{array}{l}28 ' 339 ' 886 \\
10 ' 398 ' 481 \\
\end{array}$ & 7'436'838 \\
\hline 2005 & $\begin{array}{c}\text { Medium } \\
\text { Large }\end{array}$ & $\begin{array}{l}38^{\prime} 937 ' 360 \\
51^{\prime} 586 ' 006 \\
\end{array}$ & $\begin{array}{r}288^{\prime} 527 ' 523 \\
43^{\prime} 694^{\prime} 989 \\
\end{array}$ & 7'675'821 \\
\hline 2006 & $\begin{array}{c}\text { Medium } \\
\text { Large }\end{array}$ & $\begin{array}{r}34 ' 956 ' 059 \\
59^{\prime} 015 ' 814 \\
\end{array}$ & $\begin{array}{l}25^{\prime} 610 ' 616 \\
49^{\prime} 988^{\prime} 273 \\
\end{array}$ & 7'376'382 \\
\hline $\begin{array}{l}\text { Totals } \\
\text { for } \\
2003- \\
2006\end{array}$ & & 259'331'189 & 188 '567'591 & 29'936'765 \\
\hline
\end{tabular}

Note: Best estimate is computed from the point estimates of the relevant parameters. The most conservative estimate is computed from the 95 percent lower confidence interval for the parameter or combination of parameters in question. 


\section{Annex}

\section{Notice regarding the Competition Law Treatment of Vertical Agreements} in the Motor Vehicle Trade

\section{Decision of the Competition Commission of 21 October 2002}

The Swiss Competition Commission issues the Notice below in consideration of the following grounds:

- Pursuant to Art. 6 of the Cartel Act (SR 251), the Competition Commission may prescribe, by way of general notices, the conditions under which particular types of competition agreements may as a rule be justified on the grounds of economic efficiency within the meaning of Art. 5 (2) LCart. If required by a need for more legal certainty, in an analogous application of Art. 6 of the Cartel Act, the Commission may also announce, by way of general notices, other principles for the application of the law.

- This communication refers to the EC Commission Regulation No. 1400/ 2002 of 31 July 2002 on the application of Art. 81 (3) of the Treaty to categories of vertical agreements and concerted practices in the motor vehicle sector, which came into force for the EEA on 1 October 2002 (here referred to as the Block Exemption Regulation). It takes account of the economic and legal conditions applicable in Switzerland. The Competition Commission thereby wishes to prevent price fixing and isolation of the Swiss market as well as to encourage internal market competition. It also wishes thereby to stimulate competition on the customer services market.

- This Notice comes into effect on 1 November 2002. It replaces the decision of the Competition Commission issued on 20 January 1997 regarding exclusive distribution contracts in the motor vehicle industry (RPW 1997/1, page 55 and RPW 1997/2, page 178).

- The (general) notice regarding the competition law treatment of vertical agreements of 18 February 2002 applies to vertical agreements in the motor vehicle trade insofar as this Notice does not make any provision.

- This Notice does not bind the Appeals Commission for Competition Matters nor the Swiss Federal Supreme Court in the interpretation of competition law provisions. 


\section{A Definitions}

\section{Art. 1 Motor Vehicles}

1 Motor vehicles are self-propelled vehicles with at least three wheels that are intended for traffic on public roads.

2 Motor vehicles within the meaning of this Notice are in particular:

a) Passenger cars intended for the carriage of persons and with not more than eight seats in addition to the driver's seat.

b) Light commercial vehicles intended for the carriage of goods or persons and with a maximum weight not exceeding 3.5 tons.

c) Lorries intended for the carriage of goods and with a maximum weight exceeding 3.5 tons.

d) Buses intended for the carriage of persons.

Art. 2 Motor Vehicle Supplier

Motor vehicle supplier means the manufacturer or importer of motor vehicles.

\section{Art. 3 Distribution Systems}

1 Distribution systems mean selective and exclusive distribution systems.

2 Selective distribution systems are distribution systems in which the motor vehicle supplier commits himself to sell the contract goods or services directly or indirectly only to dealers or repairers who have been chosen on the basis of particular characteristics and in which these dealers or repairers commit themselves not to sell the relevant good or services to unauthorised dealers or independent repairers. This applies without prejudice to the possibility for sales of spare parts to independent repairers and the duty to make available to independent operators all required technical information, diagnostic and other equipment and training required for the repair and maintenance of motor vehicles or for the implementation of environmental protection measures.

3 Exclusive distribution systems are distribution systems for which each of the authorised dealers is allocated its own sales territory by the motor vehicle supplier.

\section{Art. 4 Active Sales}

The possibility of active sales exists when a member of a distribution system is entitled to approach the end user directly for the sale or marketing of his motor vehicles. 


\section{Art. 5 Restrictions}

Restrictions within the meaning of this Notice are in particular:

a) Agreements between motor vehicle suppliers and dealers which restrict the sale of motor vehicles by dealers to end users in that, for example, the remuneration of the dealer or the sales price are made dependent on the place where the vehicle is ordered or the place of residence of the end user.

b) Agreements between motor vehicle suppliers and dealers which restrict the sale by dealers to end users in that, for example, a premium related to the place where the motor vehicle is ordered or any other form of discriminatory product delivery to dealers is agreed upon.

c) Agreements between motor vehicle suppliers and dealers that do not oblige authorised repairers within a motor vehicle supplier distribution system to perform work under warranty, free servicing and vehicle recall work in respect of every motor vehicle sold in Switzerland or in the EEA bearing the relevant trademark.

Art. 6 Authorised Repairer

An authorised repairer is a provider of repair and maintenance services for motor vehicles who belongs to a distribution system set up by the motor vehicle supplier.

\section{Art. 7 Independent Repairer}

1 An independent repairer is a provider of repair and maintenance services for motor vehicles who does not belong to a distribution system set up by the motor vehicle supplier whose motor vehicles he repairs or maintains.

2 Independent repairers within the meaning of this Notice include authorised repairers within the distribution system of a motor vehicle supplier who carry out repair and maintenance services for motor vehicles of other suppliers to whose distribution system they do not belong.

\section{Art. 8 Spare Parts}

Spare parts are goods that are installed in or on a motor vehicle to replace a component of that vehicle. This also includes goods such as lubricants which are necessary for the use of the motor vehicle (when these are used for maintenance or repair services) with the exception of fuel.

\section{Art. 9 Original Spare Parts}

1 Original spare parts are components which are of the same quality as the components used for the assembly of a new motor vehicle, provid- 
ed these are manufactured to the specifications and production requirements given by the motor vehicle manufacturer for the manufacture of components or spare parts for the relevant motor vehicle.

2 Original spare parts also include spare parts which are manufactured on the same production line as the components.

3 It is assumed unless the contrary is proved that spare parts are original spare parts when the manufacturer certifies that these parts are of the same quality as the components used for the manufacture of the relevant vehicle and that they have been manufactured to the specifications and production requirements of the motor vehicle manufacturer.

Art. 10 Spare Parts of Matching Quality

When at any time a manufacturer of spare parts can evidence that the spare parts manufactured by him are of the same quality as those used for the assembly of a motor vehicle, these spare parts are considered to be of matching quality.

\section{B Rules}

Art. 11 Basic Principle

In principle the Competition Commission regards distribution agreements as material restrictions of competition within the meaning of Art. 5 (1) LCart which cannot be justified on grounds of economic efficiency, if they have as their subject matter one of the clauses set out in Art.12-15.

\section{Art. 12 Price Fixing}

The following clauses are as a rule material restrictions of competition and not justified: Restriction of the possibilities for dealers or repairers to set sales prices themselves; the motor vehicle supplier may however set maximum prices or price recommendations, insofar as these do not amount to a fixed or minimum sales price as a result of pressure from or the guarantee of incentives from one of the contract parties.

Art. 13 Sale in the Context of an Exclusive Distribution System The following clauses are as a rule material restrictions of competition and not justified:

a) Restrictions on the possibility for end users in Switzerland or independent sellers in Switzerland to order motor vehicles without any restriction from an authorised dealer in Switzerland or a dealer who is active in the EEA. 
b) Restriction of the sale of motor vehicles by members of an exclusive distribution system in Switzerland to end users in the EEA and to independent sellers in the EEA.

c) Restriction of active and passive sales of motor vehicles by members of an exclusive distribution system to end users or unauthorised dealers who are located in markets where a selective distribution system is applied.

Art. 14 Sales in the Context of a Selective Distribution System The following clauses are as a rule material restrictions of competition and not justified:

a) Restriction of the possibility for end users in Switzerland, members of a selective distribution system in Switzerland or sellers in Switzerland who are commissioned by an end user in Switzerland to order motor vehicles without restriction from an authorised dealer in Switzerland or a dealer active in the EEA.

b) Restrictions on the sale of motor vehicles by members of a selective distribution system in Switzerland to end users in the EEA, authorised dealers in the EEA and sellers who are commissioned by an end user in the EEA.

c) Restriction of active sales of motor vehicles, spare parts for all types of motor vehicle or repair and maintenance services to end users resident in Switzerland or in the EEA by members of a selective distribution system in Switzerland or by members of a selective distribution system in the EEA who are active on the retail level of trade.

d) Restriction of the possibility for members of a selective distribution system to carry out active sales of passenger vehicles or light commercial vehicles through additional sales or delivery points in Switzerland or in the EEA where selective distribution is applied.

e) Restriction of passive sales by members of a selective distribution system to end users or unauthorised dealers who are located in a market for which exclusive territories have been allocated.

\section{Art. 15 Customer Service}

1 The following clauses are as a rule material restrictions of competition and not justified:

a) Restriction of the right of an authorised repairer to limit its activities to the provision of repair and maintenance services and the distribution of spare parts.

b) Restriction of the possibility for dealers to subcontract the provision of repair and maintenance services to authorised repairers; the mo- 
tor vehicle supplier can however require that the dealer gives end users the name and address of the authorised repairer or repairers before conclusion of the sales contract and, if one of the authorised repairers is not in the vicinity of the point of sale, to inform the end user how far away the repairer or repairers in question are located from the point of sale.

c) Restriction on the sale of motor vehicle spare parts by members of a selective distribution system to independent repairers in Switzerland or repairers active in the EEA which use these parts for the repair and maintenance of motor vehicles.

d) Restriction of the possibility for a supplier of original spare parts or spare parts of matching quality, repair tools or diagnostic or other equipment to sell these goods to authorised or independent dealers in Switzerland or in the EEA and to authorised or independent repairers active in Switzerland or in the EEA or to end users.

e) Restriction of the possibility for a dealer or an authorised repairer to obtain original spare parts or spare parts of matching quality from a third party of its choice in Switzerland or in the EEA and to use these for the repair or maintenance of motor vehicles; the right of the supplier of new motor vehicles to require the use of original spare parts supplied by the vehicle manufacturer for work carried out under warranty, free servicing or vehicle recall work is unaffected.

f) A refusal of motor vehicle suppliers to provide independent operators with access to any technical information, diagnostic or other equipment, tools including any relevant software or training required for the repair and maintenance of its motor vehicles, or for the implementation of environmental protection measures.

2 Access under paragraph 1f) must include in particular the unrestricted use of the electronic control and diagnostic systems of a motor vehicle ${ }^{16}$, the programming of these systems in accordance with the motor vehicle supplier's standard procedures, the repair and maintenance instructions and the information required for the use of diagnostic and servicing tools and other equipment. This access must be given promptly to independent operators in a nondiscriminating and proportionate way. The information must be useable. The access to objects that are covered or protected by an intellectual property right or constitute know-how must not be refused in an abusive way.

16 A motor vehicle supplier is however entitled to withhold technical information that could allow third parties to circumvent or turn off in-built anti-theft devices, to reset electronic systems or to manipulate for example speed limiting devices, provided such protection against circumvention, elimination, resetting or manipulating such devices cannot be achieved through other less restrictive means. 


\section{Art. 16 Distribution of Several Brands}

The following clauses are as a rule a material restriction of competition and not justified:

Direct or indirect obligations ${ }^{17}$ that require the members of a distribution system not to sell motor vehicles or spare parts from competing motor vehicle suppliers nor to provide repair and maintenance services for motor vehicles from competing motor vehicle suppliers.

\section{Art. 17 Termination of Contract}

Provisions regarding termination of contracts are as rule material restrictions of competition and not justified if the termination is not reasoned in writing and if the following modalities of termination are not respected:

a) Contract duration of at least five years; obligation on the contracting parties to notify the fact that it will not be extended more than six months in advance.

b) For contracts with an indefinite term, a notice period of at least two years.

c) For contracts with an indefinite term, a shortened notice period of at least one year provided

i) the motor vehicle supplier is obliged by legal provisions or by special agreement to pay appropriate compensation on termination of the contract, or

ii) where it is necessary for the motor vehicle supplier to terminate the contract in order to restructure the entire distribution network or at least a substantial part thereof.

\section{Art. 18 Transition Provisions}

1 This Notice enters into force on 1 November 2002.

2 Existing distribution agreements in the motor vehicle trade are to be brought into line with this Notice prior to 1 January 2005.

3 Art. 14 d) applies from 1 October 2005.

17 This applies in particular to obligations on dealers to organise distribution of each individual mark through a separate independent legal person, to sell motor vehicles from other motor vehicle suppliers in different exhibition areas and to appoint specific sales personnel for different motor vehicle brands. An obligation on dealers to sell motor vehicles from other motor vehicle suppliers in a particular area of the exhibition space, to avoid confusion between the brands, will not be regarded as a material restriction on competition by the Competition Commission. 


\section{Artikel - Articles}

\section{Die negativen Auswirkungen des krisenbezogenen Handelsprotektionismus auf die Schweizer Aussenwirtschaft \\ Simon J. Evenett und Johannes Fritz}

As a small and open economy, Switzerland is not independent from developments in international trade policy. The present article analyses to what extent Swiss foreign commercial interests have been harmed by discriminatory implemented measures since November 2008. The strong geographic and sectorial concentration of Swiss trade explains the relatively small direct effects found in the data. By contrast, Swiss commercial interests face a considerably bigger challenge from indirect effects in the form of artificial competition in third countries. Targeted export subsidies could lead to additional pricing pressure for half of total Swiss exports by trade value.

Die Schweiz ist als kleine und offene Volkswirtschaft nicht unabhängig von den Entwicklungen internationaler Handelspolitik. In der vorliegenden Arbeit wird analysiert in welchem Umfang Schweizer Aussenhandelsinteressen seit November 2008 von diskriminierenden handelspolitischen Massnahmen betroffen sein könnten. Eine Analyse der Exponiertheit von Schweizer Einund Ausfuhren gegenüber den Hauptakteuren diskriminierender Handelsmassnahmen erklärt die relativ geringe direkte Betroffenheit der Schweizer Exportwirtschaft. Allerdings erwächst der Schweizer Wirtschaft eine ungleich grössere, indirekte Herausforderung durch künstlichen Wettbewerb in Drittstaaten. Gezielte Exportsubventionen könnten die Mehrheit der Schweizer Exporteure zusätzlicher Preiskonkurrenz aussetzen.

\section{Competition Law and Europe's open Borders: The Case of Motor Vehicle Distribution in Switzerland}

\section{Simon J. Evenett and Michael Meier}

This paper contains an independent* empirical analysis of the effect of a Notice, issued by the Swiss Competition Commission in 2002 concerning vertical agreements between manufacturers and distributors of motor vehicles, on the degree to which the subsequent prices of cars in Switzerland exceeded those charged on the same models in neighbouring countries. Evidence presented here implies a non-transitory reduction in the degree of price discrimination against Swiss customers of medium- and large-sized cars in the years 
after the Notice came into effect. The total gain to Swiss buyers of cars is very conservatively estimated to be six times the total cumulative budget of the Swiss Competition Commission during the years 2003-2006; the best estimate of those gains exceed a quarter of a billion Swiss Francs during the same period. By 2006 the cumulative price reduction of the Swiss Competition Commission's action resulted in average savings per medium- and large-sized car that are estimated to be 929 and 2113 Swiss Francs, respectively. Moreover, the recurring annual gain to Swiss consumers of this single action by the Swiss Competition Commission is conservatively estimated to exceed ten times the latter's current annual budget, providing some indication of the "value for money" that effective competition law can have, even in economies with ostensibly open borders.

* In short independent here means "independent of the Swiss Competition Commission." That is, the authors collected all of the data for this study themselves (a process that took a substantial amount of time and effort), conducted the empirical analysis themselves, and drafted this text themselves without any guidance or funding from the Swiss Competition Commission. The Swiss Competition Commission did not make any information available to the authors that is not available to the general public. In order to better understand the decision taken by the Swiss Competition Commission, the authors did speak to officials at that body. In response to a request from the Swiss Competition Commission, the authors did provide a summary of the findings of this study earlier in the year.

Dieser Beitrag enthält eine unabhängige* empirische Analyse des Effekts einer durch die Schweizerische Wettbewerbskommission (WEKO) erlassenen Bekanntmachung betreffend vertikaler Absprachen zwischen Herstellern und Händlern von Motorfahrzeugen über die Höhe der Preisdifferenz zwischen schweizerischen und ausländischen Modellen identischer Art. Die Resultate zeigen eine anhaltende Reduktion im Grad der Preisdiskriminierung gegenüber Schweizer Käufern von mittelgrossen und grossen Fahrzeugen in den Jahren nach Inkrafttreten der Bekanntmachung. Die konservativ geschätzten Gewinne für Schweizer Fahrzeugkäufer sind sechs Mal so hoch wie das kumulierte Budget der Schweizerischen Wettbewerbskommission in den Jahren 2003 bis 2006. Der bevorzugte Schätzer dieser Gewinne liegt höher als eine Viertelmillion Schweizer Franken in der besagten Periode. Im Jahr 2006 lagen die Gewinne pro mittelgrosses Fahrzeug bei 929 Schweizer Franken, jene für ein grosses Fahrzeug bei 2113 Schweizer Franken. Konservative Schätzungen zeigen, dass die sich jährlich wiederholenden Gewinne für Schweizer Konsumenten das Budget der Schweizerischen Wettbewerbskommission um das Zehnfache übersteigen. Die Untersuchung des Falls zeigt, dass sich effektives Wettbewerbsrecht auch bei angeblich offenen Grenzen auszahlt.

* Unabhängig bezieht sich hier auf die Schweizerische Wettbewerbskommission. Das heisst, dass die Autoren alle Daten der Studie selber gesammelt haben. Dieser Prozess war zeitintensiv. Die Durchführung der empirischen Untersuchung sowie die Verfassung des vorliegenden Texts lagen vollständig in der Verantwortung der Autoren. Die Schweizerische Wettbewerbs- 
kommission hat den Autoren keinerlei Informationen zur Verfügung gestellt, die nicht öffentlich verfügbar sind. Um die Entscheidungen der Wettbewerbskommission besser zu verstehen, wurden Gespräche mit deren Mitgliedern durchgeführt. Als Antwort auf eine entsprechende Anfrage haben die Autoren der Wettbewerbskommission anfangs Jahr eine Zusammenfassung zugestellt.

\section{Wettbewerb: Fluch und/oder Segen? Gebhard Kirchgässner}

In the philosophical literature, there exist rather positive but also rather negative evaluations of competition. It has, of course, positive and negative effects, for single individuals, for their moral behaviour, but also for the whole society. At least for the latter, the dynamic aspects are more relevant than the static ones. In connection with its negative effects it is frequently demanded that competition should be eliminated or at least restricted. This does often, however, not take into account its evolutionary nature; competition cannot just be switched on and off. Thus, the government has only limited options to make competition possible, to enhance or to suppress it. Because the suppression of competition always implies a restriction of individual liberty rights, it is not a trivial matter under which conditions and how such restrictions can be justified.

In der philosophischen Literatur finden sich sehr positive, aber auch sehr negative Beurteilungen des Wettbewerbs. Schliesslich kann er auch positive und negative Auswirkungen haben, für die einzelnen Individuen, und zwar sowohl für ihre persönliche Situation als auch für ihr moralisches Verhalten, aber auch für die Gesellschaft insgesamt. Für letzteres sind die dynamischen im Allgemeinen wichtiger als die statischen Effekte. In Zusammenhang mit seinen negativen Auswirkungen wird häufig eine Ausschaltung oder zumindest Beschränkung des Wettbewerbs gefordert. Dabei wird freilich sein evolutionärer Charakter meistens verkannt; er lässt sich nicht einfach an- und abschalten. Daher hat der Staat auch nur begrenzte Handlungsmöglichkeiten, um Wettbewerb zu ermöglichen, zu fördern, oder zu unterdrücken. Da eine Unterdrückung des Wettbewerbs immer auch eine Einschränkung individueller Freiheitsrechte bedeutet, stellt sich die Frage, wann und wie eine solche Einschränkung gerechtfertigt werden kann. 


\section{Autoren - Authors}

\section{Prof. Dr. Simon J. Evenett}

University of St. Gallen

SIAW-HSG

Bodanstrasse 8

CH-9000 St. Gallen

simon.evenett@unisg.ch

\section{Johannes Fritz}

University of St. Gallen

SIAW-HSG

Bodanstrasse 8

CH-9000 St. Gallen

\section{Prof. Dr. Dr. h.c. Gebhard Kirchgässner}

Universität St. Gallen

SIAW-HSG

Bodanstrasse 8

CH-9000 St. Gallen

Schweiz

gebhard.kirchgaessner@unisg.ch

\section{Michael Meier}

University of St. Gallen

SIAW-HSG

Bodanstrasse 8

CH-9000 St. Gallen

michael.meier.ch@gmail.com 
Reproduced with permission of the copyright owner. Further reproduction prohibited without permission. 